\title{
Erratum
}

\section{Temporal dimensions of vulnerability to crime in economic sectors: Theory meets evidence and spawns a new framework}

\author{
Noel Klima \\ Department of Criminal Law and Criminology, IRCP - Institute for \\ International Research on Criminal Policy, Ghent University, \\ Universiteitstraat 4, Ghent B-9000, Belgium. \\ E-mail: Noel.Klima@UGent.be
}

Risk Management (2012) 14, 248. doi:10.1057/rm.2012.4

Correction to: Risk Management (2012) 14, 93-108. doi:10.1057/rm.2011.7

A typographical error has been detected after the article was initially published.

Table 1 was missing a category section, the omission of which misrepresented the data and the findings that followed. We apologise that this was not noticed before first publication. Please see below for the corrected table:

Table 1: Unpacking vulnerability to crime

\begin{tabular}{|c|c|c|c|}
\hline \multicolumn{4}{|c|}{ Vulnerability to crime } \\
\hline \multicolumn{2}{|c|}{ Pre-crime conditions } & \multicolumn{2}{|c|}{ Post-crime conditions } \\
\hline Opportunities & Inadequate controls & Lack of recovery & Lack of adaptation \\
\hline $\begin{array}{c}\text { Weak financial } \\
\text { situation of } \\
\text { enterprise }\end{array}$ & $\begin{array}{l}\text { Inadequate sector } \\
\text { entrance checks }\end{array}$ & No financial back-ups & $\begin{array}{l}\text { Lack of communication } \\
\text { on crime risks }\end{array}$ \\
\hline $\begin{array}{l}\text { Lack of crime } \\
\text { prevention } \\
\text { measures }\end{array}$ & $\begin{array}{l}\text { Lack of key positions } \\
\text { checks }\end{array}$ & $\begin{array}{l}\text { No redundancy/back-up } \\
\text { in business systems }\end{array}$ & $\begin{array}{l}\text { Lack of employee } \\
\text { awareness }\end{array}$ \\
\hline $\begin{array}{l}\text { Inadequate } \\
\text { legislation }\end{array}$ & $\begin{array}{l}\text { Lack of business } \\
\text { partnership checks }\end{array}$ & $\begin{array}{l}\text { No contingency/ } \\
\text { continuity planning }\end{array}$ & $\begin{array}{l}\text { No flexibility in } \\
\text { enterprise structures }\end{array}$ \\
\hline
\end{tabular}

